\title{
Związki Bogusława Firkowicza z Krymem
}

\author{
ALEKSANDER BABADŻAN
}

Między Karaimami z Krymu a ich współbraćmi mieszkającymi na Litwie, w Łucku czy Haliczu, zawsze istniała stała łączność i wzajemna pomoc. Wymieniano korespondencję, handlowano, wspólnie świętowano, zawierano związki małżeńskie i przesiedlano się, wydawano i rozsyłano modlitewniki. Już Czacki ${ }^{1}$ w 1807 r. pisał, że religijny zwierzchnik Karaimów litewskich znajduje się na Krymie, w Dżuft-Kale. Szczególnie wyraźnie wzajemna pomoc przejawiała się w latach 1915-1919, w czasach wojennej ewakuacji Karaimów z Litwy do Rosji, kiedy uciekinierom okazano wszelką możliwą pomoc i wsparcie, zapewniając im dach nad głową, pracę, możliwość nauki.

Związki z Krymem były obecne także w całym życiu Bogusława Firkowicza (1865-1915).

W 1880 r. po ukończeniu szkoły karaimskiej i państwowej szkoły powiatowej w Trokach, wyjeżdża na Krym. Tam, w Ormiańsku kontynuuje edukację religijną jako uczeń Zachariasza Chorczenki, jednego z największych w owym czasie znawców teologii i literatury karaimskiej. 1 kwietnia 1885 r., po pomyślnym złożeniu egzaminów uzyskuje prawo piastowania stanowisk duchownych i powraca do Trok, gdzie pracuje jako nauczyciel w szkole karaimskiej, a od 1901 r. - jako hazzan.

Już jako hacham trocki uczestniczy w pierwszym Karaimskim Zjeździe Narodowym, który odbył się w Eupatorii w dniach 1-9 listopada 1910 r. Na zbiorowej fotografii delegatów widzimy go w tradycyjnej karaimskiej czapce karakułowej.

O jego związkach z Krymem i szacunku, jakim się tam cieszył, świadczy zachowany list jego żony, Kamili Firkowiczowej, wysłany z Ostrowa, a datowany 16 stycznia1916 r., zawierający słowa podziękowania za 100 rubli pomocy przekazanej jej przez Taurydzki Zarząd Duchowny w związku z przedwczesną śmiercią męża.

A oto wydarzenie z ostatnich lat związane z Bogusławem Firkowiczem i Krymem. W 2003 r. do antykwariatu, w którym pracuje S. Bołoteniuk, mąż Natalii Kazas, przyniesiono z miasteczka Stary Krym dawne księgi karaimskie, modli- 
tewniki i katechizmy. Wszystkie, co ciekawe $\_$w języku rosyjskim. Niektóre z nich nosiły podpis właściciela „Grigorij Nikif. Morozow”. Książki pozbawione były stron tytułowych, pierwszych i ostatnich kartek, wszystkie były podniszczone wskutek długotrwałego użytkowania. Wśród nich oprócz znanych rosyjskojęzycznych publikacji karaimskich - „Katechizmu” Duwana² i tomów modlitewników "Głos Jakuba ${ }^{3 ”}$ - znalazły się trzy książki, o których istnieniu nam, współczesnym, nie było wiadomo:

„Kolejność modlitw u karaimów, ułożona skrótowo przez hachana i głównego nauczyciela karaimów Abrahama Samojłowicza Firkowicza. Przełożył I. B. N. Firkowicz. Carycyn. Typo-litografia W. R. Fiedorowej 19014".

„Modlitwy w dniu odpuszczenia grzechów (10-go dnia miesiąca tiszri). Tom II. Z języka hebrajskiego przełożył I. B. N. Firkowicz. Carycyn. Typo-litografia W. R. Fiedorowej 1896".

Pozbawiona karty tytułowej książka rozpoczynającą się, Modlitwami przed obiadem i po obiedzie na cały rok w obrządku karaimskim", zaś kończąca się „Modlitwą za pomyślność cara”. Treść tej książki nie pokrywała się całkowicie z zawartością I tomu „Głosu Jakuba”, ale była bardzo zbliżona. Nasuwał się stąd wniosek, że jest to tom I wydania carycyńskiego z 1896 roku.

Jak następnie ustalono, istniało jeszcze jedno, wcześniejsze wydanie książki opisanej w punkcie 1. Była to „Kolejność modlitw u karaimów, ułożona skrótowo przez hachana i głównego nauczyciela karaimów Abrahama Samojłowicza Firkowicza. Przełożył I. B. N. Firkowicz", wydana w Carycynie w typo-litografii E. P. Fiedorowa w 1892 roku. Między pierwszym wydaniem tej książki z 1892 r. a drugim z 1901 r. występują niewielkie różnice: w drugim wydaniu zwiększono rozmiar czcionki, dodano dwie i usunięto cztery części oznaczone numerami.

Tak oto zostały odkryte trzy wydania modlitewników karaimskich, które dla Rosjan wyznających religię karaimską przetłumaczył i opracował Bogusław Firkowicz (skrót I. B. N. oznacza Izaak-Bogusław Nisanowicz, czyli syn Nisana).

Historia powstania i peregrynacji tych karaimów słowiańskiego pochodzenia nie została jeszcze w pełni poznana. Według jednej wersji pojawili się oni wskutek przyjęcia religii od Chazarów i skupiali się w odrębnych gminach wyznaniowych. Oficjalna wersja rozpowszechniana przez stale ich prześladującą cerkiew prawosławną, która obecnie nazywa ich „subbotnikami”, a dawniej zwała „judejstwującymi”, czyli „zżydziałymi”, głosi, że pojawili się oni około 1470 r., kiedy z Kijowa do Nowogrodu przyjechał książę Michał Olelkowicz, potomek

${ }^{2}$ Duvan Â, Katihizis", osnovy karaimskago zakona. Rukovodstvo k" obučenïu ZakonuBožiü Karaimskago ünošestva. S.-Peterburg: Tipografiâ Ėttungera, 1890.

${ }^{3}$ Malecki, P.A., Glas Iakova : molitvy karaimov na ves'god : s podrobnym ukazaniem poriâdka bogosluzheniâ, s zametkami o molitve, religii, prazdnikakh i postah. Vil'na : Tip. I. I. Pirozhnikova, 1910. 2 v.

${ }^{4}$ Firkovič, Abraham, Porâdok molitv dlâ karaimov sostavlennyi v krattce gahamom i glavnym učitelem karaimov Avraamom Samoilovičem Firkovičem ; perevel I. B. N. Firkovič. Caritcyn : Tipo-lit. V.R. Fedorovoi, 1901.

${ }^{5}$ Molitva v' den' vseproščenìa (10-go dnâ měsâca Tišri) perevel s" Drevne-Evrejskago âzyka I. B. N. Firkovič. Caritcyn" : Tipo-lit. E. I. Fedorova, 1896. 2 v' 
księcia litewskiego Olgierda. W jego świcie znajdował się przyboczny medyk i astrolog, Karaim z Kaffy, Zachariasz Skara (Scharia). Wspomina się, że był on młody, „nieco starszy niż dwadzieścia lat” i nawiązał kontakty z inteligencją nowogrodzką, wśród której byli duchowni. Przywiózł on księgę zawierającą sześć opatrzonych komentarzami tablic służących do obliczania faz księżyca. Nauczał sposobu korzystania z tej księgi i przekonywał rozmówców, że Bóg jest jedyny, że Chrystus nie jest Bogiem, że nie należy czcić ikon i przedstawianych na nich świętych, że podstawą wiary jest Dziesięcioro Przykazań i wyłącznie Stary Testament. Przebywał on w Nowogrodzie cztery miesiące, może dłużej, po czym wyjechał razem z księciem do Kijowa, a następnie powrócił na Krym. W Nowogrodzie zaś, a później w Moskwie, rozprzestrzeniała się „herezja zżydowiałych”, którą cerkiew prawosławna tępiła wszelkimi możliwymi metodami. W $1893 \mathrm{r}$. w Guberni Astrachańskiej była nawet wniesiona sprawa z powodu wydanej w Carycynie książki B._Firkowicza, którą starano się wycofać ze sprzedaży i odebrać wierzącym. Mimo uzyskanego zezwolenia cenzury na druk, dokonano konfiskaty 47 jej egzemplarzy. Więcej skonfiskować nie zdołano, później zaś z tej samej drukarni wyszło jeszcze wydanie w języku karaimskim. Do nas zaś modlitewniki te trafiły z rąk jednego z Rosjan wyznających religię karaimską, Grigorija Nikiforowicza Morozowa.

Tak więc po upływie ponad wieku od dokonanych przekładów i po prawie 100 latach od śmierci Bogusława Firkowicza dowiedzieliśmy się więcej o jego związkach z Krymem i poznaliśmy nieznane fakty dotyczące jego działań służących umacnianiu religii karaimskiej. 